\title{
MYÖHÄISMODERNISSA IKÄNORMIT MURTUVAT - IKÄ ON ITSESTÄ KIINNI
}

\section{lälle annettuja merkityksiä ammatillisessa osaamisessa ja sen kehittämisessä}

\author{
Kun tutkittiin työntekijäin käsityksiä siitä, mikä on iän merkitys \\ ammattillisessa osaamisessa ja osaamisen kehittymisessä, nousi aiempaa \\ selvemmin esiin ikääntyvien työntekijäin kokemuksellinen osaaminen \\ sekä monet työelämän tarvitsemat osaamisen vahvuudet. Kronologista \\ ikää tärkeämmäksi koettiin persoonalliset ominaisuudet. Kun ikää, \\ osaamista ja sen kehittymistä tarkastellaan, tulisikin tarkasteltavaksi \\ ottaa työtehtävien laatu, kokemuksen merkitys ja kokemuksen suhde \\ ikään.
}

\section{SUSANNA PALONIEMI}

I kääntymistä ja työtä koskettavista teemoista on keskusteltu vilkkaasti viimeisten vuosien aikana. Ikääntyvien työntekijöiden ${ }^{1}$ asema työelämässä huolestuttaa ja kiinnostaa niin Suomessa ja kuin muuallakin Euroopassa. Taustalla on uhkakuvia työvoiman saatavuuteen liittyvistä ongelmista, taloudellisista rasitteista sekä osaamispääoman menetyksestä ja inhimillisten voimavarojen riittävyydestä. Vaikka ikääntyviä työntekijöitä koskettavat teemat ovat olleet reilun vuosikymmenen ajan esillä eurooppalaisessa keskustelussa, on osaamista ja oppimista alettu tarkastella ja tutkia varsin myöhään. Puhe työelämän muutoksesta, lähinnä teknisestä ja taloudellisesta, on yhdessä ikärakenteen muutoksen ja eläkehakuisuuden kanssa nostanut esiin kysymyksen ikääntyvien työntekijöiden osaamisen laadusta. Näkökulmia ovat niin ammatillinen peruskoulutus kuin laajemmin valmiudet ylläpitää osaamista.

Ikään perustuvien ratkaisujen ja ikäsyrjinnän kokemukset ovat tulleet esille erityisesti ikääntyneiden pitkäaikaistyöttömien kokemuksissa, mutta myös työelämässä mukana olevien työelämän ura- ja koulutusmahdollisuuksia koskevien ratkaisujen yhteydessä. Ikään perustuvaa syrjintää koetaan tutkimusten mukaan paitsi rekrytoinnis- sa myös ammatilliseen koulutukseen pääsyssä (Korvajärvi 1999; Walker \& Maltby 1997) ja työpaikan muissa toimissa ja ratkaisuissa (Kouvonen 1999). Sekä kansallisesti että eurooppalaisesti on toteutettu mittavia hankkeita ikääntyvien työntekijöiden aseman parantamiseksi ja hyvien käytäntöjen muodostamiseksi.

Tarkastelen artikkelissa

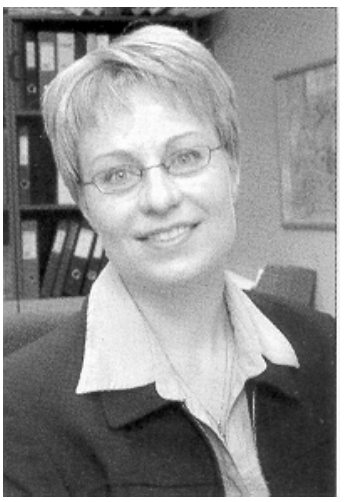

Susanna Paloniemi iän ja ikääntymisen merkitystä ammatillisessa osaamisessa ja sen kehittämisessä työntekijöiden ikäkäsitysten kautta. Ikäkäsityksillä tarkoitetaan fenomenografisen lähestymistavan (Marton 1994) mukaisesti niitä erilaisia tapoja, joina eri-ikäiset työntekijät kokevat, ymmärtävät ja käsittävät iän merkityksen osaamisen ja osaamisen kehittämisen alueella. Teoreettisesti ikäkäsitykset kiinnittyvät ikääntymistä ja työssä suoriutumista sekä ikääntyviä työntekijöitä koskevia asenteita tarkasteleville tutkimusalueille. 


\section{IKÄÄNTYMINEN JA TYÖSSÄ SUORIUTUMINEN \\ TUTKIMUKSEN KOHTEENA}

Ikääntymisen vaikutusta työssä suoriutumiseen on lähestytty pääsääntöisesti toimintakykyisyyden näkökulmasta. Tutkimustieto ikääntymisen vaikutuksista toimintakyvyn eri osa-alueille ei ole yksiselitteistä ja sisältää useita tulkinnallisia ongelmia. Keskeisin näistä ongelmista liittyy poikkileikkausasetelmien käyttöön, jolloin ikävaikutuksen erottaminen historiallisista tekijöistä on kyseenalaista. Lisäksi toimintakyvyn eri osa-alueet painottuvat erilaisessa työssä eri tavoin, mikä lisää tulkinnallisuutta. Osaamisen ja sen kehittämisen kannalta olennaisin ikääntymisen vaikutuksia työkykyyn tarkasteleva tutkimus sijoittuu pääsääntöisesti psyykkiseen toimintakykyyn. Tältä osin keskeisimmät ikääntymisen tuomat muutokset koskevat psykomotoriikkaa, muistia, oppimista ja ajattelutoimintoja, itseä koskevia käsityksiä ja motivaatiota sekä toimintaa ja minäkäsitystä (Ruoppila \& Suutama 1994).

Kognitiivisen ikääntymisen tutkimuksissa on keskitytty tarkastelemaan kognitiivista kehitystä elämänkulussa sekä mahdollisten muutosten vaikutuksia mm. työssä suoriutumiseen. Perustoimintojen ohella mielenkiinto on viime vuosina yhä voimakkaammin kohdistunut kognitiivisten rakenteiden tutkimukseen (esimerkiksi taidot, valmiudet ja kokemus). Perustoiminnoista poiketen niiden on todettu pysyvän jokseenkin muuttumattomina myöhäiseen ikään tai kehittyvän iän myötä. Iän myötä samana pysyvinä tai edelleen kehittyvinä kognitiivisina toimintoina on pidetty kiteytynyttä älykkyyttä, semanttista, proseduraalista- ja prospektiivistä muistia, arkipäivän sosiaalisten ja käytännöllisten ongelmien ratkaisua sekä kokemuksellista asiantuntijuutta (kts. katsaus Hallsten 1996, 144-149). Informaalissa oppimisessa näiden toimintojen vaikutus näkyy formaaliin oppimiseen verrattuna $\mathrm{mm}$. vähäisempinä ikäryhmien välisinä eroina.

Ikääntymisen ja osaamisen sekä ikääntymisen ja oppimisen välisen problematiikan ymmärtämisessä keskeinen tutkimusalue on käytännöllisen älykkyyden tutkimus (mm. Torff \& Sternberg 1998, 112). Käytännöllinen älykkyys pysyy iän myötä samana tai kehittyy edelleen. Siinä näyttäisi olevan olennaista luonteeltaan informaali tieto, jota useat tutkijat kutsuvat nimellä hiljainen, sanaton tai äänetön tieto. Vaikka hiljaisen tiedon käsitteen määrittelystä ei ollakaan täysin yksimielisiä2 ${ }^{2}$, näyttää kuitenkin siltä, että sille luonteenomaista on juuri käytännöllisyys ja yhteys kokemuksellisuuteen. Hiljaisen tiedon merkitys työelämässä sekä sen yhteydet käytännölliseen älykkyyteen elämänkulussa luovat varttuneemman aikuisen oppimisesta työelämäkontekstissa paljon myönteisemmän kuvan kuin perinteinen kykyjen tutkimus.

Kognitivistista lähestymistapaa on kritisoitu erityisesti kontekstuaalisuuden puutteesta. Kehityksellinen ja kontekstuaalinen näkökulma (esimerkiksi Lyng 1996, 17-18; Sternberg \& Horvath 1999) ottavat huomioon paitsi yksilölliset elämänhistorian vaikutukset esimerkiksi koulutus- ja työkokemukseen myös sen muuttuvan sosiaalisen kontekstin, jossa sekä formaalia että käytännöllistä osaamista hyödynnetään. Myös Lahn (2000, 43-47) korostaa sosiokulttuurisen näkemyksen merkitystä. Yksinkertaistettu kognitivistinen malli soveltuu formaalin ja selkeästi jäsennellyn oppimisen kontekstiin, mutta ei niinkään jokapäiväisen elämän oppimisprosessien kuvaamiseen, joiden ymmärtämiseen sosiokulttuuriset ja elämänkulun kehityksellisyyttä korostavat lähestymistavat voivat tuoda uutta näkökulmaa. Osaamisen ja sen kehittämisen tutkimuksessa viime vuosina voimistunut tulkinnallinen näkökulma (Sandberg 2000a, 2000b) korostaa sosiokulttuurisen näkökulman tavoin kontekstuaalisuutta ja yksilöllisen kehitys- ja muutosprosessin merkitystä.

\section{SUHTAUTUMINEN IKÄÄNTYVIIN TYÖNTEKIJÖIHIN RISTIRIITAISTA}

Käsityksiä iän ja ikääntymisen merkityksestä työssä on tutkimuksissa lähestytty pääsääntöisesti asennetutkimuksin. Käytetty käsitteistö on vaihdellut tutkimuksesta toiseen ja ilmiötä on lähestytty sellaisten käsitteiden avulla kuin asenne, uskomus, myytti, käsitys, havainto tai suhtautumistapa. Huolimatta käsitteiden kirjosta on tutkimuksissa yhdenmukaisesti pyritty selvittämään käsityksiä siitä, miten ikääntyminen vaikuttaa työssä suoriutumiseen. Lisäksi tutkimuksissa on usein joko piiloisesti tai avoimemmin ollut mukana olettamus siitä, että suhtautuminen ikääntyviin työntekijöihin vaikuttaa heitä koskeviin käytännön ratkaisuihin ja toimenpiteisiin. Osittain tästä syystä suurin osa näistä tutkimuksista on keskittynyt tarkastelemaan työnantajien asenteita, ja tutkimuksissa yhtenä osa-aluee- 
na ovat olleet asenteet ikääntyvien työntekijöiden oppimista kohtaan. Vähemmälle huomiolle ovat jääneet eri-ikäisten työntekijöiden asenteet ikääntymistä ja työssä suoriutumista sekä ikääntymistä ja oppimista kohtaan.

Oppimistapojen ja-menetelmien, aikuisuuden kehityksen ja työkyvyn tutkimukset osoittavat, että vaikka oppiminen iän myötä hidastuu, kyky oppia uusia asioita ja taitoja säilyy. Kuitenkin vaikka tieto ikääntymisen ja osaamisen sekä ikääntymisen ja oppimisen välisestä suhteesta on monelta osin viimeisen kahdenkymmenen vuoden aikana lisääntynyt ja muuttunut, on suhtautuminen ikääntyviä työntekijöitä kohtaan monien eri tutkimusten (mm. Ahola \& Huuhtanen 1995; Taylor \& Walker 1994) mukaan kaksijakoista niin yhteiskunnassa, organisaatioissa kuin eri-ikäisten henkilöstöjen keskuudessa. Vaikka myös osittain ristiriitaisiakin tuloksia on esitetty, voidaan tutkimustuloksia pitää kaksijakoisuuden osalta melko yhdenmukaisina: karttuvalla iällä ja ikääntymisellä uskotaan olevan sekä myönteisiä että kielteisiä vaikutuksia. Myönteisinä nähdään ikääntyvien työntekijöiden työetiikka ja -moraali sekä persoonallisuuden kypsyminen iän myötä. Sen sijaan oppimiskyvyn ja oppimisnopeuden uskotaan vähenevän, kun ikää tulee lisää. Myös oppimismotivaation uskotaan hiipuvan.

Huolestuttavaa on se, että käsitys iän karttumisen ja oppimisen välisestä suhteesta perustuu edelleen voimakkaasti ennakkoluuloihin ja tiedon puutteeseen. Nuorempiin työntekijöihin verrattuna ikääntyviä työntekijöitä pidetään joustamattomampina, kykenemättömämpinä omaksumaan uutta teknologiaa ja vaikeammin koulutettavina. Tämän vuoksi ikääntyvillä työntekijöillä ei uskota olevan koulutustarvetta, ja siten heidän osallistumishalukkuuttaan koulutukseen ja kiinnostustaan oppimista kohtaan pidetään vähäisenä. Kielteinen suhtautuminen voi heikentää koulutus- ja kehitysmahdollisuuksia, mikä edelleen osaltaan ylläpitää kielteisiä käsityksiä (Legge, Cant, O’Loughlin \& Sinclair 1997). Ei siis niinkään kronologinen ikä sinänsä, vaan ikäsyrjivät käytännöt ovat nostaneet esiin kysymyksen "ikäsensitiivisestä" henkilöstöpolitiikasta (Tikkanen, Valkeavaara \& Lunde 1996) ja ikäjohtamisesta (Juuti 2001). Ennakkoluulot ikääntymisen ja osaamisen sekä ikääntymisen ja oppimisen välisestä suhteesta ovat tekijä, joka on osaltaan muokkaamassa organisaatioiden toiminta- ja oppimiskulttuureja.

\section{TUTKIMUSAINEISTO JA SEN ANALYYSI}

Seuraavaksi esittämäni käsitykset iän ja osaamisen sekä iän ja osaamisen kehittämisen suhteesta perustuvat tutkimukseeni "Ikä, osaaminen ja oppiminen"3. Sen tavoitteena oli selvittää ja kuvata niitä merkityksiä, joita työntekijät antavat iälle ja ikääntymiselle ammatillisessa osaamisessa ja sen kehittämisessä. Taustalla on kysymys siitä, miten yksilö kokee iän ja ikääntymisen merkityksen työelämässä. Iän ja ikääntymisen problematiikkaa lähestyn tarkastelemalla niitä merkityksiä, joita työntekijät antavat iälle ja ikääntymiselle suhteessa osaamiseen ja sen kehittämiseen omassa työkontekstissaan. Lähteenä on tutkimukseni haastatteluaineisto.

Tutkimukseni on osa eurooppalaista tutkimusprojektia 'Working Life Changes and Training of Older Workers' (Worktow ${ }^{4}$ ). Worktow on toimintatutkimussuuntautunut ja se käsittelee työelämän muutoksia ja ikääntyvien työntekijöiden koulutusta (Tikkanen ym. 2002). Työntekijöiden ikäkäsityksiä tarkasteleva tutkimukseni on siinä oma itsenäinen kokonaisuus ja sen aineistona olen käyttänyt laajemman projektin yhteydessä kerättyä kansallista osa-aineistoa.

Esittämäni ikäkäsitykset perustuvat kuuden keskisuomalaisen pk-yrityksen työntekijöiden haastatteluihin. Yrityksistä kolme oli palveluaalalta ja kolme informaatiopainotteiselta toimisto- ja suunnittelualalta. Palveluyritykset edustivat tuotantoa ja vähittäiskauppaa, pankki- ja rahoituspalveluita sekä tukku- ja vähittäiskauppaa. Informaatiopainotteisista toimisto- ja suunnittelutyön pk-yrityksistä kaksi edusti prosessi-, laitos-, koneenrakennus- ja koneautomaatiosuunnittelua ja yksi pientalojen rakennussuunnittelua ja tuotantoa. Yhteensä 43 iältään 24-62-vuotiasta yritysten työntekijää (keski-ikä 41 vuotta) osallistui teemoittain eteneviin yksilö- ja ryhmähaastatteluihin. Heistä palvelualalla työskenteleviä oli 21 ja toimisto- ja suunnittelutyössä 22. Toimialojen sukupuolittuneisuus näkyi osallistujajoukossa siten, että palvelualan työssä enemmistö osallistuneista oli yritysten henkilöstörakenteiden mukaisesti naisia. Vastaavasti informaatiopainotteisen toimisto- ja suunnittelualan työntekijöistä suurin osa oli miehiä.

Haastatteluiden teemat käsittelivät 1) muutoksia työssä ja työympäristössä, 2) osaamista ja sen kartoitusta, 3) ikää ja kokemusta osaamisessa, 4) 
työelämän joustoja sekä 5) tulevaisuutta. Tutkimusaineiston keräsivät keväällä 1999 Worktowprojektin tutkijat. Aineiston analyysissä nojauduttiin Martonin (1994, 4428) esittämiin fenomenografisen aineiston analyysivaiheisiin. Aineistoon perehtymistä seurasi aineiston supistaminen, jonka jälkeen siirryttiin sisällölliseen tarkasteluun. Muodostetuista osa-aineistoista jäljitettiin erilaisia ikäkäsityksiä ilmaisevia ajatuskokonaisuuksia. Tavoitteena oli tuoda esille yksilöiden tuottamien erilaisten ikää ja ikääntymistä koskevien arkikäsitysten variaatio riippumatta siitä, voidaanko niitä jonkin perusteen mukaisesti asettaa järjestykseen tai ovatko ne "oikeita" suhteessa tieteellisen tiedon tuottamiin tai tutkijan omaksumiin käsityksiin. Apuna käytettiin yhtäläisyyksien ja erojen vertailun metodia (Glaser \& Strauss 1967) sekä edelleen käsitysten ryhmittelyssä kuvauskategorioihin kontekstianalyysiä (Theman 1983). Analyysin viimeisessä vaiheessa saadut kuvauskategoriat sijoitettiin yksittäisiin haastatteluihin. Ikäkäsitykset kuvataan seuraavassa vertikaalisesti koko aineiston tasolla.

\section{IÄN MONET MERKITYKSET OSAAMISESSA JA SEN KEHITTÄMISESSÄ}

Työntekijöiden käsitykset iän ja ikääntymisen merkityksestä ammatillisessa osaamisessa ja sen kehittämisessä kietoutuivat monelta osin toisiinsa. Työntekijöiden käsitysten mukaan osaaminen oli dynaaminen, monitahoinen ja jatkuva prosessi. He pitivät osaamisen jatkuvaa ylläpitoa yhtenä osaamisen alueena. Samoin ajateltiin työyhteisöissä ero toimialan. Iän ja ikääntymisen merkitys osaamisessa ja sen kehittämisessä, osaamisen monitahoisuus ja työelämän muutos kietoutuvat ajattelussa yhteen. Tyypillistä oli myös, että iän ja ikääntymisen merkitystä tarkasteltiin pääosin suhteessa nuoruusvuosiin. Nuorempien ohella myös iäkkäämmät työntekijät pohtivat iän ja ikääntymisen merkitystä niin oman elämänkulkuunsa kuin suhteessa työyhteisönsä eri-ikäisiin työntekijöihin.

Haastatteluaineiston pohjalta paikansin neljä kategoriaa, jotka kuvaavat osaamiseen ja sen kehittymiseen kohdistuvia ikäkäsityksiä. Osaamista koskevat ikäkäsitykset olivat: iän merkityksettömyys osaamisessa, ikä osaamisen ja kokemuksen kartuttajana, iän merkityksellisyys tässä ajassa ja ikä osaamisen heikentäjänä. Vastaavasti osaamisen kehittämistä koskevat ikäkäsitykset olivat: iän merkityksettömyys osaamisen kehittämisessä, iän myötä osaamisen kehittäminen helpottuu ja korostuu, iän myötä osaamisen kehittäminen vaikeutuu ja hidastuu ja iän myötä motivaatio osaamisen kehittämiseen heikkenee. Taulukkoihin 1 ja 2 on koottu työntekijöiden ikäkäsitykset, niitä luonnehtivat ilmentymät sekä poimintoja aineistoesimerkeistä.

Työntekijöiden osaamista ja sen kehittämistä koskevat ikäkäsitykset ovat tiivistettävissä perussuhtautumistavaltaan kolmeen kategoriaan: ikäneutraaliin, myönteiseen ja kielteiseen. Voimakkaimmin työntekijöiden käsityksissä korostui $i k \ddot{a}$ neutraalius ja iän kategorian häviäminen: työssä käytettävä osaaminen ja sen kehittäminen nähtiin iästä riippumattomana. Iän merkityksettömyys kietoutui voimakkaasti sekä ikääntymisen että osaamisen ja oppimisen yksilöllisyyteen. Ikää merkittävimpinä osaamisessa ja sen kehittämisessä pidettiin yksilöllisiä ominaisuuksia, joista korostuivat kehitykselliset ja asenteelliset elementit, esimerkiksi motivaatio itsensä kehittämiseen. Edelleen työolosuhteet, työn sisällöt ja työn tarjoamat haasteet nousivat olennaisiksi. Iän merkityksettömyys kiinnittyi myös aikaan, jolloin oppimis- ja kehittymisvaatimusten koetaan koskettavan kaikenikäisiä. Iän merkityksettömyyden painottuminen kiinnittyy voimakkaasti myöhäismodernissa iästä käytyyn keskusteluun (Nikander 2001; Rantamaa 2001), jonka kohteena on toisaalta yhdenmukaisen iän häviäminen ja toisaalta kronologisen iän korostuminen.

Ikää pidettiin merkityksellisenä muissa kategorioissa. Keskeisimmin esiin nousi myönteinen, kokemuksen karttumiseen sidonnainen, persoonallista kasvua ja kokemuksellista asiantuntijaosaamista korostava ikäkäsitys. Sekä osaamisessa että sen kehittämisessä pidettiin myönteisenä kokemuksen karttumista. Kokemuksen merkitystä korostettiin laaja-alaisen osaamisen ja käytännöllisen ja soveltavan oppimisen lähteenä. Haastatteluissa puhe iästä kietoutui voimakkaasti puheeseen kokemuksesta ja elämänkulusta. Ikääntyvien työntekijöiden osaamisen vahvuutena näyttäytyi aineistossa kokemuksen kautta syntynyt hiljainen tieto. Sen kehittyminen ainakin jossain määrin edellyttää työkokemusten monipuolisuuden ohella ajallista kertymää.

Työntekijöiden ikäkäsityksille oli ominaista iän tarkasteleminen elämänkulun viitekehyksessä. Elämänkulun ja ikääntyvän työntekijän elämän- 


\begin{tabular}{|c|c|c|}
\hline $\begin{array}{l}\text { OSAAMISEN } \\
\text { IKÄKÄSITYS }\end{array}$ & $\begin{array}{l}\text { Ikäkäsityksen luonnehdinta ja } \\
\text { ilmenemisen variaatiot }\end{array}$ & Aineistoesimerkit \\
\hline $\begin{array}{l}\text { IÄN MERKITYKSET- } \\
\text { TÖMYYS } \\
\text { OSAAMISESSA }\end{array}$ & $\begin{array}{l}\text { - Henkilökohtaisten ominai- } \\
\text { suukien korostaminen } \\
\text { - Ikääntymisen yksilöllisyys } \\
\text { - Iän merkityksettömyys } \\
\text { suhteessa työyhteisöön } \\
\text { - Iän merkityksettömyys suhtees- } \\
\text { ssa työssä suoriutumiseen } \\
\text { - Kronologisen iän vastakkais- } \\
\text { määrittely }\end{array}$ & $\begin{array}{l}\text { "... ihminen sinänsä ratkaisee, } \\
\text { että onko se nyt minkä ikäinen ta- } \\
\text { hansa, että, henkilökohtaiset omi- } \\
\text { naisuudet ne on ainakin minun } \\
\text { mielestä tärkeämpi asia kuin ikä." } \\
\text { "... et ikäerot ei näy oikeestaan } \\
\text { ollenkaan. Vuorovaikutus toimii } \\
\text { hyvin eri-ikäisten tyttöjen välil- } \\
\text { lä." } \\
\text { "... iästä et ei se ole este työn te- } \\
\text { kemiselle. Et jos on vireä niin mikä } \\
\text { estää ihmistä olemasta työssä." }\end{array}$ \\
\hline $\begin{array}{l}\text { IKÄ OSAAMISEN JA } \\
\text { KOKEMUKSEN } \\
\text { KARTOITTAJANA }\end{array}$ & $\begin{array}{l}\text { - Kokemuksen karttuminen iän } \\
\text { myötä elämänkulussa } \\
\text { - Persoonallinen kasvu, rohkeus, } \\
\text { varmuus ja oman osaamisen } \\
\text { jakaminen } \\
\text { - Kokemusosaamisen relevanssin } \\
\text { kyseenalaistaminen }\end{array}$ & $\begin{array}{l}\text { ”... kun sitä kokemusta ei tuu il- } \\
\text { man sitä tiettyy ikää." } \\
\text { "... et se kokemus tulee, koke- } \\
\text { muksesta oppii itsevarmuutta." } \\
\text { "... vasta opiskelun päättänyt } \\
\text { niin sillä ei oo vielä semmosta } \\
\text { kokemusta. [..] en tiijä sitten, että } \\
\text { jos oot alalla ollu viiis vuotta tai } \\
\text { viistoista vuotta niin konko sillä } \\
\text { sitten enää merkitystä." }\end{array}$ \\
\hline $\begin{array}{l}\text { IÄN MERKITYK- } \\
\text { SELLISYYS } \\
\text { TÄSSÄ AJASSA }\end{array}$ & $\begin{array}{l}\text { - Eri-ikäisten työntekijöiden } \\
\text { erilainen osaaminen } \\
\text { - Nuorempien ja iäkkäämpien } \\
\text { työntekijöiden vertaaminen }\end{array}$ & $\begin{array}{l}\text { "... taas sitten nuoremmat ei oo } \\
\text { kerenny niinku semmosta käy- } \\
\text { tännön työkokemusta kentältä } \\
\text { hankkia ja sellainen suunnittelu- } \\
\text { taito voi olla vähäisempää." } \\
\text { "... ne [nuoremmat] on semmoi- } \\
\text { sia näppäily-tekniikan taitajia, } \\
\text { taitavia käyttämään kaikki ohjel- } \\
\text { mia, mutta suunnittelutaitoo ei } \\
\text { oo välttämättä." }\end{array}$ \\
\hline $\begin{array}{l}\text { IKÄ OSAAMISEN } \\
\text { HEIKENTÄJÄNÄ }\end{array}$ & $\begin{array}{l}\text { - Fyysisen työ- ja toimintakyvyn } \\
\text { heikkeneminen } \\
\text { - Ikääntyminen biologisena } \\
\text { prosessina } \\
\text { - Ikääntymisen yksilöllisyys }\end{array}$ & $\begin{array}{l}\text { ”... fyysinen ikä tulee jossain vai- } \\
\text { heessa vastaan silleen heikenty- } \\
\text { västi." } \\
\text { ".. tietysti ikä tuo mukanaan jo- } \\
\text { takin rajoitteita. Tämmönen fyy- } \\
\text { sinen systeemi, tai kyky liikkua } \\
\text { tuolla, tai yleensä joku niinku tiet- } \\
\text { ty terävyys, niin on siinä vähän } \\
\text { eroa." }\end{array}$ \\
\hline
\end{tabular}




\begin{tabular}{|c|c|c|}
\hline $\begin{array}{l}\text { Osaamisen kehittämisen } \\
\text { ja oppimisen ikäkäsitys }\end{array}$ & $\begin{array}{l}\text { Ikäkäsityksen luonnehdinta } \\
\text { ja ilmenemisen variaatiot }\end{array}$ & Aineistoesimerkit \\
\hline $\begin{array}{l}\text { IÄN MERKITYKSET- } \\
\text { TÖMYYS } \\
\text { OSAAMISEN } \\
\text { KEHITTYMISESSÄ }\end{array}$ & $\begin{array}{l}\text { - Henkilökohtaisten } \\
\text { ominaisuuksien ja } \\
\text { motivaation korostaminen } \\
\text { - Ikääntymisen ja oppimisen } \\
\text { yksilöllisyys } \\
\text { - Työtehtävien ja työn sisältöjen } \\
\text { merkitys osaamisen } \\
\text { kehittämisessä } \\
\text { - Osaamisen kehittämisen } \\
\text { vaatimus iästä riippumatta } \\
\text { - Kronologisen iän vastakkais- } \\
\text { määrittely }\end{array}$ & $\begin{array}{l}\text { "Minusta se [ikä] vaikuttaa eri ih- } \\
\text { misiin ihan eri tavalla. Se ei oo ol- } \\
\text { lenkaan niinkään se ikäkysymys } \\
\text { vaan se on lähinnä henkilökysy- } \\
\text { mys." } \\
\text { "Enkä mä usko, että sillä on mitään } \\
\text { tekemistä, että miten vanha oot jos } \\
\text { sää oot kiinnostunut siitä, mitä sä } \\
\text { opiskelet." } \\
\text { "... ne jotka jaksaa ja haluaa py- } \\
\text { syä mukana, ne myös pysyy mu- } \\
\text { kana, riippumatta siitä iästä." }\end{array}$ \\
\hline $\begin{array}{l}\text { IÄN MYÖTÄ } \\
\text { OSAAMISEN } \\
\text { KEHITTYMINEN } \\
\text { HELPOTTUU JA } \\
\text { KOROSTUU }\end{array}$ & $\begin{array}{l}\text { - Elämänkulun näkökulma } \\
\text { osaamisessa ja oppimisessa } \\
\text { - Iän sosiaalinen määrittyminen } \\
\text { - Persoonallinen kypsyys } \\
\text { tuo kärsivällisyyttä ja pitkä- } \\
\text { jänteisyyttä } \\
\text { - Oppimisen kohdentaminen } \\
\text { ja suuntaaminen olennaiseen } \\
\text { kokemuksen pohjalta } \\
\text { - Työn merkityksen } \\
\text { korostuminen }\end{array}$ & $\begin{array}{l}\text { ”... mun mielestä ois paljon hel- } \\
\text { pompaa, kun tulee ikää enemmän, } \\
\text { ja jotkut asiat sitten, ne kiinnostaa- } \\
\text { kin huomattavasti enemmän." } \\
\text { "... nuorempana oli niin paljon } \\
\text { muuta, että se oli lähinnä pakolli- } \\
\text { nen. [..] Nyt olis silleen paljon vas- } \\
\text { taanottavampi [..] olis enemmän } \\
\text { aikaa siihen opiskeluun käyttää } \\
\text { vanhemmalla iällä." } \\
\text { "Tajuaa, että tää on nyt semmos- } \\
\text { ta, mitä kannattaa opiskella. [..] Se } \\
\text { on niinku tarkotuksenmukaista." }\end{array}$ \\
\hline $\begin{array}{l}\text { IÄN MYÖTÄ } \\
\text { OSAAMISEN } \\
\text { KEHITTYMINEN } \\
\text { VAIKEUTUU JA } \\
\text { HIDASTUU }\end{array}$ & $\begin{array}{l}\text { - Ikääntymismuutosten merkitys } \\
\text { - Osaamisen kehittäminen } \\
\text { formaalina opiskeluna } \\
\text { - Uuden oppiminen }\end{array}$ & $\begin{array}{l}\text { "Asioiden muistamiseen on tehtä- } \\
\text { vä työtä enemmän kuin nuorena." } \\
\text { "Oppimiskyky on hyvä mutta kiel- } \\
\text { tämättä vie enemmän aikaa." }\end{array}$ \\
\hline $\begin{array}{l}\text { IÄN MYÖTÄ } \\
\text { MOTIVAATIO } \\
\text { OSAAMISEN } \\
\text { KEHITTÄMISEEN } \\
\text { HEIKKENEE }\end{array}$ & $\begin{array}{l}\text { - Muuttuvat osaamisvaatimukset } \\
\text { ja elämänvaiheen rajapinnan } \\
\text { kohtaaminen } \\
\text { - Työn ja eläkkeen vastakkain- } \\
\text { asettelu } \\
\text { - Elämänkulun näkökulma } \\
\text { - Iän sosiaalinen määrittyminen }\end{array}$ & $\begin{array}{l}\text { "... on semmonen ryhmä tuolta } 40- \\
50 \text { jotka on syrjäytyny sen takia } \\
\text { että ne ei joko jaksa, tai ne ei ha- } \\
\text { lua, tai niillä ei oo motivaatiota et- } \\
\text { siä, löytää, paivittää tietojaan." } \\
\text { "Mutta tulee niinku lähelle eläke- } \\
\text { ikää niin kyllä varmaan niinku ru- } \\
\text { pee. En tiijä, onko sitä kiinnostu- } \\
\text { nut vielä asioista." }\end{array}$ \\
\hline
\end{tabular}


vaiheen kontekstissa iän ja ikääntymisen merkitys tuli esille kahdella eri tavalla. Toisaalta se tuli esiin myönteisessä mielessä siten, että osaamisen ja sen kehittämisen merkitys korostuvat iän myötä. Käsityksissä nostettiin esiin se, että karttuva ikä mahdollistaa persoonallisen kasvun ja kypsymisen. Myös työn merkityksen katsottiin korostuvan iäkkäämpänä elämässä. Toisaalta työntekijät tuottivat elämänkulun viitekehyksestä vastakkaisen käsityksen iän ja ikääntymisen merkityksestä. Vastakkain asettuivat työelämä ja eläkeaika. Tällä katsottiin olevan seurauksia erityisesti työntekijän halukkuuteen kehittää omaa osaamistaan.

Iän kielteinen merkitys osaamisessa tuli esiin paitsi eläkehakuisuuden pohdintana, myös iän ja työelämän muutosten sekä iän ja työ- ja toimintakyvyn välisen suhteen tarkasteluina. Työ- ja toimintakykyä heikentäviä ikääntymisen aiheuttamia muutoksia työntekijät toivat haastatteluissa esille niukasti. Maininnat koskivat fyysisen toimintakyvyn heikkenemistä ja oppimisen hidastumista iän myötä. Aiemmissa tutkimuksissa juuri työkyvyn ja terveyden heikentymistä on pidetty tärkeimpänä vanhenemiseen liittyvänä tekijänä (Uutela, Palosuo \& Haukkala 1994, 20-21). Tässä esille tulleiden työ- ja toimintakykyä heikentävien ikääntymismuutosten merkitys kyseenalaistettiin korostamalla ikääntymisen ja osaamisen yksilöllisyyttä sekä osaamisen kokonaisvaltaisuutta. Työelämän muutosten kontekstissa osaamisessa painotettiin tietoteknistä osaamista ja jatkuvaa kehittämistä. Iän myötä lisääntyneet uuden oppimisen vaikeudet, kuten oppimisen hidastuminen ja harjoituksen tarpeen kasvu, liitettiin voimakkaimmin juuri tietoteknisen osaamisen alueelle. Ikääntyvien työntekijöiden asema työelämässä näyttäytyikin tältä osin työntekijöiden käsityksissä heikompana kuin nuorempien työntekijöiden.

Toisaalta ikä tuli merkitykselliseksi nimenomaan suhteessa elettävään aikaan ja työelämän muutoksiin. Ikä on merkityksellinen työelämässä juuri tässä ajassa, nykykontekstissa, jolloin työelämässä olevien eri-ikäisten työntekijöiden koulutustaustat poikkeavat olennaisesti toisistaan ja osaamisen vahvuudet painottuvat eri alueille. Ajan suhde ikääntymiseen on tuttu gerontologian APC-ongelma. Erilaiset ilmiöt voivat liittyä eri tavoin kronologiseen ikään (Age), ajankohtaan (Period) ja kohorttiin (Cohort). Elämänkulun ja ikääntymisen ajallisuus tarkoittaa, että iän, ajan- kohdan ja kohorttiin kuulumisen merkitystä on usein vaikea erottaa toisistaan (Jyrkämä 2001, 129-132). Ikä koettiin merkittäväksi juuri eri-ikäisten kohorttien tarkastelun näkökulmasta. Kielteisille ikäkäsityksille oli tyypillistä vertailuasetelma nuorempien ja iäkkäämpien työntekijöiden välillä.

Ikäkäsityksiä luonnehti sekä osaamisen että osaamisen kehittämisen osalta moninaisuus ja ambivalenttius. Tulos on samansuuntainen aiempien ikäkäsityksiä tarkastelleiden asennetutkimusten kanssa. Jokaisessa haastattelussa tuli esille useampia ikäkäsityksiä, jotka olivat perussuhtautumiseltaan joko toisiaan tukevia tai toisilleen vastakkaisia. Ikä näytti työntekijöiden käsitysten perusteella saavan tämän päivän työelämässä osaamisen ja sen kehittämisen kontekstissa hyvin ristiriitaisia ja erilaisia merkityksiä. Myös muut Worktow-projektin tutkimustulokset (Tikkanen 2000) antavat viitteitä olettaa, että ikääntymisen merkitys työssä suoriutumiselle on kiinteässä yhteydessä työtehtäviin ja työn sisältöihin.

\section{MONTA IKÄÄ AJASSA}

Ikäkäsitysten tarkastelu erilaisten ikämäärittelyiden (Laslett 1989; Tikka 1994) valossa nostaa esiin iän monet kasvot. Iän merkityksettömyys pohjaa voimakkaasti kronologisen iän kautta tapahtuvaan vastakkaismäärittelyyn. Kysymyksessä voidaan tulkita olevan pyrkimys iän määrittämiseen muusta kuin kronologisuudesta käsin, tai ainakin pyrkimyksestä tuoda rinnalle muita vaihtoehtoisia ja samanaikaisesti olemassa olevia ikämäärittelyjä. Kronologisen iän määrittelyiden lisäksi aineistossa esille tulleet viittaukset fyysiseen vanhenemiseen ja työ- ja toimintakyvyn heikkenemiseen ovat ymmärrettävissä selkeimmin biologisen iän ja ikääntymisprosessin kautta. Tälle ikämäärittelylle on olennaista se, miltä ikääntyminen biologisena ja fyysisenä prosessina tuntuu, ja millaisen kokemuksen se tuottaa itsestä työntekijänä ja oppijana akselilla ennen ja nyt.

Ikäkäsitykset kiinnittyivät haastatteluissa kiinteästi elämänkulkuun. Ikä pyykittää ja vaiheistaa elämänkulkua, jolloin suhde kronologisen ja sosiaalisen iän välillä tulee merkitykselliseksi. Työn ja eläkkeen vastakkainasettelun kautta iän merkitys työelämässä määrittyi sosiaalisin perustein ja keskeiseksi nousi rajanveto toisen ja kolmannen 
iän rajan välillä. Työntekijät kokivat eläkkeelle siirtymisen ja eläkeaikaan suuntautumisen houkuttelevampina kuin työn kehittämisen. Käsitykset ovat samansuuntaisia kuin työ- ja eläkeasenteita tarkastelleissa tutkimuksissa, joiden mukaan työstä eläkkeelle siirtymistä selittävät toisaalta sekä eläkkeelle työntävät että vetävät tekijät (Gould 2002; Huuhtanen \& Piispa 1999). Toisaalta elämänkulun kautta tapahtuva sosiaalisen iän määrittely piti sisällään myös myönteisiä elementtejä. Tällöin korostui erityisesti kokemus työelämässä tarvittavan asiantuntijaosaamisen keskeisenä osa-alueena ja lähteenä.

Ikäkäsityksissä korostuu kautta linjan yksilöllisyys. Yksilöllisyys ja iän merkityksettömyyden korostaminen toivat voimakkaasti mukaan iän persoonallisen ja kokemuksellisen määrittämisen. Persoonallisen iän korostuminen työntekijöiden käsityksissä asettaa yhdenmukaisen ikämäärittelyn ja -käsityksen kyseenalaiseksi. Ikäkäsityksissä kyseenalaistuivat sekä vanhuuden että iän käsitteet. Ikäkysymystä keskeisemmäksi nousivat yksilön persoonallisuus, elämänhistorian valinnat, työympäristöä koskettavat tekijät sekä kokemus.

Ikäkäsitysten monimuotoisuus on tulkittavissa toisaalta iän moniulotteisuutena ja toisaalta iän yhdenmukaistumisena. Näitä on pidetty tyypillisenä myöhäismodernin yhteiskunnan tunnusmerkkeinä (Giddens 1991), jossa kronologiseen ikään ja sitä kautta määrittyvään elämänkulun vaiheeseen liittyvät ikänormit murtuvat ja yhdenmukaistavat elämänkulun ikävaiheita. Iän merkityksettömyyden korostumista on selitetty iättömyyden kokemuksella (Jyrkämä 1996, 108-111). Iästä on tullut individualisoitu (Julkunen \& Pärnänen 2002) sillä tavalla, että iän katsotaan olevan itsestä kiinni. Toisaalta iän merkityksettömyyden korostuminen itsessään voidaan tulkita kielteiseksi ja syrjiväksi (Andrews 1999).

Merkille pantavaa on viime vuosina ollut iän merkityksen korostuminen työelämässä (Rantamaa 2001, 68-69). Tästä kertovat osaltaan niin ikääntyviä työntekijöitä koskettava julkinen keskustelu kuin tutkimus ja päätöksentekokin. Erilaisissa toimenpiteissä ikääntyvät työntekijät on pyritty määrittämään ikävaiheen kautta. Työntekijöiden ikäkäsitysten moniulotteisuus nosti esiin neuvottelun ikääntyvän työntekijän määrittämisestä suhteessa elämänkulun ikä- ja elämänvaiheisiin. Ikääntyvää työntekijää määritettiin ensisijaisesti elämänvaiheen, ei ikävaiheen näkökul- masta. Kuitenkaan kronologista ikää ei ollut täysin mahdollista ohittaa. Pohtiessaan omaa ikää ja ikääntymistään, osaamistaan ja sen kehittämistä suhteessa työyhteisön muihin jäseniin ja omaan elämänkulkuunsa ikääntyvän työntekijän elämänvaiheen neuvottelu sai perusteita sekä kronologisesta iästä ja tähän liittyvästä kokemuksesta että elämänvaiheesta ura- ja elämänkulussa. Rinnakkaiset ja ristiriitaiset ikäkäsitykset haastoivat perinteisen ja yhdenmukaisen kronologiseen ikään nojaavan elämänkulun ikävaiheittaisen jäsentämisen myös osaamisen ja sen kehittämisen näkökulmasta.

\section{HAASTEENA OSAAMISEN HYÖDYNTÄMINEN TYÖYHTEISÖISSÄ}

Tutkimuksessa esille nousseet työntekijöiden käsitykset osaamisen ja sen kehittämisen ja iän suhteesta eivät täysin tue aiempien tutkimusten stereotyyppisiä käsityksiä iän ja osaamisen sekä iän ja oppimisen välisestä suhteesta. Päinvastoin ne antavat aihetta olettaa, että ikääntyvillä työntekijöillä on kokemuksellista osaamista ja tiettyjä osaamisen vahvuuksia, joita tarvitaan työelämässä. Sekä yksilöllisyys, osaamisen suhteellisuus ja kontekstuaalisuus että relevantin kokemuksen merkitys tulivat haastatteluissa esille. Työntekijöiden käsityksissä (kronologista) ikää merkittävämpiä osaamisessa ja sen kehittämisessä työelämässä olivat työntekijän persoonalliset ominaisuudet, halukkuus oman osaamisen kehittämiseen sekä kokemuksellisen osaamisen hyödyntäminen ja jakaminen. Iän, osaamisen ja sen kehittämisen välisessä tarkastelussa tulisikin laajemmin ottaa huomioon niin työtehtävän laatu kuin relevantin kokemuksen merkitys ja edelleen kokemuksen suhde ikään (Warr 1998, 36-39).

Ikäkäsitysten monimuotoisuus antaa edelleen aihetta laajempaan työelämän ikäystävällisen henkilöstöpolitiikan ja -johtamisen kehittämiseen. Osaamisen ja sen kehittämisen kontekstisidonnaisuus yhdessä iän monimuotoisuuden kanssa haastaa työelämän aikuiskoulutuksen kehittämään eri-ikäisten työntekijöiden osaamisen hyödyntämistä ja jakamista työyhteisöissä. Se, miten organisation sisällä osaaminen jakautuu eri-ikäisten työntekijäin kesken, korostuu erityisesti silloin, kun suuri määrä työntekijöitä on jäämässä eläkkeelle samanaikaisesti. Yksi mahdollisuus toteuttaa ikäjohtamista on jakaa osaamista työ- 
yhteisössä työn suunnittelun ja organisoinnin avulla. Iäkkäämmälle työntekijälle mahdollisuus käyttää omaa osaamista uudella tavalla tarjoaa välineitä itsensä kehittämiseen ja kokemukseen oman osaamisen hyödyllisyydestä ja arvostuksesta. Mahdollisuuden uudenlaiseen osaamisen käyttöön tarjoavat esimerkiksi erilaiset mentorointiohjelmat ja konsultaatiomallit. Osaamisen jakaminen työyhteisössä työtä uudelleen organisoimalla palvelee ikääntyvän työntekijän näkökulmasta mahdollisesti myös kokemusosaamisen käyttöä ikääntymismuutosten kompensaationa (Salthouse 1997, 22-23).

Ikää ja ikääntymistä työkontekstissa tarkastelevissa hankkeissa on korostunut toisaalta yksilön vastuu voimavarojen kehittämisessä ja toisaalta työn ja sen organisoinnin keskeisyys (Ilmarinen, Louhevaara, Huuhtanen \& Näsman 1999). Voimakkaimmin on korostunut työ- ja toimintakykyisyyden ylläpitämistä korostava lähtökohta, joskin viime aikoina on esitetty myös muita lähtökohtia eri hankkeissa. Tässä iän ja ikääntymisen määrittymistä tarkasteltiin erityisesti osaamisen ja sen kehittämisen kontekstissa. Tulokset haastavat entistä voimakkaammin yhteistoiminnan sekä työntekijän voimavarojen (toimintakyky, osaaminen, arvot) että työn (työympäristön, -yhteisön, johtamisen) organisoinnin kehittämiseksi sekä iän että osaamisen monimuotoisuuden perusteella.

\section{LÄHTEET}

Ahola, K. \& Huuhtanen, P. (1995). Ikäasenteet ja oikeudenmukaisuus työssä. Ikääntyvä arvoonsa -ohjelma. Työterveyslaitos ja Työsuojelurahasto.

Andrews, M. (1999). The seductiveness of agelessness. Ageing and Society 19 (3), 301-318.

Baltes, P. B. \& Staudinger, U. M. (toim.) (1996). Interactive minds. Life-span perspectives on the social foundation of cognition. Cambridge: University Press.

Eraut, M. (2000). Non-formal learning, implicit learning and tacit knowledge in professional work. Teoksessa F. Goffield (toim.) The necessity of informal learning. ESRC Learning Society series. University of Bristol: Policy, 12-31.

Giddens, A. (1991). Modernity and self-identity. Self and society in the late modern age. Cam- bridge: Polity.

Glaser, B. G. \& Strauss, A. L. (1967). The discovery of grounded theory: strategies for qualitative research. Chigago: Aldine.

Gould, R. (2002). Varhaiseläke, työttömyysputki vai työssä jatkaminen? [posteriesitys] Aktiivinen ja elämään suuntautuva vanheneminen -foorumi. 11.-12.2.2002. Jyväskylä.

Hallsten, L. (1996). Arbete och psykologiska åldersförändringar. Teoksessa G. Aronsson \& Å. Kilbom (toim.) Arbete efter 45? Historiska, psykologiska och fysiologiska perspektiv på äldre i arbetslivet. Solna: Arbetslivsinstitutet, 133-172.

Huuhtanen, P. \& Piispa, M. (1999). Attitudes towards early retirement and work. Teoksessa J. Ilmarinen \& V. Louhevaara (toim.) FinnAge - respect for the aging: action programme to promote health, work ability and well-being of aging workers in 1990-96. Finnish Institute of Occupational Health. Research reports 26, 19-30.

Ikääntyvät työelämässä (1996). Ikääntyvien työllistymisedellytysten parantamista selvittäneen komitean mietintö. Komiteamietintö 1996:14. Työministeriö.

Ilmarinen, J., Louhevaara, V., Huuhtanen, P. \& Näsman, O. (1999). Developing and testing of models and concepts to promote work ability during ageing. Teoksessa J. Ilmarinen $\&$ V. Louhevaara (toim.) FinnAge - respect for the aging: action programme to promote health, work ability and well-being of aging workers in 1990-96. Finnish Institute of Occupational Health. Research reports 26, 263 278.

Julkunen, R. \& Pärnänen, A. (2002). Tehostuvan työelämän ikäpolitiikat [esitelmä]. Aktiivinen ja elämään suuntautuva vanheneminen-foorumi. 11.-12.2.2002. Jyväskylä.

Juuti, P. (2001). Ikäjohtaminen. JTO-tutkimuksia 3. Työministeriö.

Jyrkämä, J. (1996). Kuka on vanha, kuka vanhus? Näkymiä vanhenemisen ja vanhuuden kokemiseen. Teoksessa T. Aittola, L. Alanen \& P. Rantamaa (toim.) Minkä ikäinen olettekaan, rouva? Jyväskylä: SoPhi, 107-118.

Jyrkämä, J. (2001). Aika tutkimuksessa ja elämänkulussa. Teoksessa A. Sankari \& J. Jyrkämä (toim.) Lapsuudesta vanhuuteen. Iän 
sosiologiaa. Tampee: Vastapaino, 117-157.

Korvajärvi, P. (1999). Ikäsyrjinnän kokemukset ja käytännöt työelämässä. Teoksessa I. Kangas \& P. Nikander (toim.) 1999. Naiset ja ikääntyminen. Gaudeamus, 85-105.

Kouvonen, A. (1999). Ikäsyrjintäkokemukset työssä ja työhönotossa. Työpoliittinen tutkimus 203. Työministeriö.

Lahn, L. (2000). Ikääntyvät oppijat oppivassa yhteiskunnassa. Teoksessa P. Sallila (toim.) Oppiminen ja ikääntyminen. Aikuiskasvatuksen 41. vuosikirja. Gummerus, 41-72.

Laslett, P. (1989). A fresh map of life. The emergence of the third age. London: Weinfeld \& Nicolson.

Legge, V., Cant, R., O’Loughlin, K. \& Sinclair, G. (1997). Australian managers' attitudes towards older workers. Teoksessa Å. Kilbom, P. Westerholm, L. Hallsten \& B. Furåker (toim.) Work after 45? Proceedings from a scientific conference held in Stockholm 2225 September 1996. Vol. 2. Arbete och hälsa 1997:29. Solna: Arbetslivsinstitutet, 214-221.

Lyng, K. (1996). Contextual and developmental aspects of adult learning. Teoksessa C. - H. Nygård \& A. Kilbom (toim.) Age and learning in working life. Solna: Arbetslivsinstitutet, 12-21.

Marton, F. (1994). Phenomenography. Teoksessa T. Husén \& T. Neville (toim.) The international encyclopedia of education. $2^{\text {nd }}$ edition, Vol. 8. London: Pergamon, 4424-4429.

Nikander, P. (2001). Age in action: membership work and stage of life categories in talk. Loughborough University. [Julkaisematon väitöskirja]

Rantamaa, P. (2001). Ikä ja sen merkitykset. Teoksessa A. Sankari \& J. Jyrkämä (toim.) Lapsuudesta vanhuuteen. Iän sosiologiaa. Tampere: Vastapaino, 49-95.

Ruoppila, I. \& Suutama, T. (1994). Psyykkisen toimintakyvyn muutokset vanhetessa. Teoksessa J. Kuusinen, E.Heikkinen, P. Huuhtanen, J. Ilmarinen, J. Kirjonen, I. Ruoppila, T. Vaherva, O. Mustapää \& S. Rautoja (toim.) Ikääntyminen ja työ. WSOY, 58-75.

Salthouse, T. (1997). Implications of adult age differences in cognition for work performance. Teoksessa Å. Kilbom, P. Westerholm, L. Hall- sten \& B. Furåker (toim.) Work after 45? Proceedings from a scientific conference held in Stockholm 22-25 September 1996. Vol 1. Arbete och hälsä 1997: 29. Solna: Arbetslivsinstitutet, 15-28.

Sandberg, J. (2000a). Competence - the basis for a smart workforce. Teoksessa R. Gerber \& C. Lankshear (toim.) Training for a smart workforce. London: Routledge, 47-72.

Sandberg, J. (2000b). Understanding human competence at work: an interpretative approach. Academy of Management Journal 43 (1). Saatavilla www-muodossa: <URL: http:// www.proquest.umi.com>. 22.4.2001.

Sternberg, R. J. \& Horvath, J. A. (toim.) (1999). Tacit knowledge in professional practice. Researcher and practitioner perspectives. Mahwah: Lawrence Erlbaum.

Taylor, P. \& Walker, A. (1994). The ageing workforce: employers' attitudes towards older people. Work, Employment and Society 8 (4), 569-591.

Theman, J. (1983). Uppfattningar av politisk makt. Acta universitatis Gothoburgensis. Göteborg studies in educational sciences 45 .

Tikka, M. (1994). Kalenteri-iästä omaelämäkerralliseen ikään. Teoksessa A. Uutela \& J. - E. Ruth (toim.) Muuttuva vanhuus. Gaudeamus, 81-101.

Tikkanen, T. (2000). Experiencing the changes brought by IT and their consequences. Teoksessa S. Tøsse et al. (toimituskunta) Reforms and policy. Adult education in Nordic countries. Trondheim: Tapir, 161-182.

Tikkanen, T., Lahn, L.C., Withnall, A., Ward, P. \& Lyng, K. (2002). Working life changes and training of older workers. TSER, IV Framework Programme. Voksenopplæringsinstituttet Research reports. Trondheim.

Tikkanen, T., Valkeavaara, T. \& Lunde, Å. (1996). Ikääntyvä työeväestö ja elinikäinen oppiminen: organisaation näkökulma. Gerontologia 10 (4), 252-261.

Torff, B. \& Sternberg, R. (1998). Changing mind, changing world: practical intelligence and tacit knowledge in adult learning. Teoksessa M. C. Smith \& T. Pourchot (toim.) Adult learning and development. Perspectives from educational psychology. New Jersey: Lawrence Erlbaum, 109-126. 
Uutela, A., Palosuo, H. \& Haukkala, A. (1994). Vanhenemiseen liittyvät mielikuvat. Teoksessa A. Uutela \& J.- E. Ruth (toim.) Muuttuva vanhuus. Gaudeamus, 7-26.

Walker, A. \& Maltby, T. (1997). Ageing Europe. Buckingham: Open University Press.

Warr, P. (1998). Learning and competence development. Teoksessa Å. Kilbom (toim.) Ageing of the workforce. Key-note presentations and abstracts form a workshop held in Brussels 23.-24.3.1998. Solna: Arbetslivsintitutet, 23-62.

\section{VIITTEET}

1 Artikkelissa on päädytty yksinkertaisuuden vuoksi käyttämään käsitettä ikääntyvät työntekijät, vaikka samanaikaisesti tiedostetaan siihen liittyvä yleistämisen ja homogenisoinnin problematiikka. Ikämäärittelyssä on nojauduttu Ikääntyvien työllistymisedellytysten parantamista selvittäneen komitean (IKOMI; Ikääntyvät työelämässä 1996) ikääntymisen ja työkyvyn välisestä suhteesta nousevaan määrittelyyn ikääntyvistä (yli 45-vuotiaista) ja ikääntyneistä (yli 55-vuotiaista) työntekijöistä. Työntekijällä viitataan artikkelissa kauttaaltaan ylipäätään henkilöstöön henkilöstöryhmästä riippumatta.
2 Hiljaisen tiedon käsitteen alkuperäisenä esittäjänä pidetään Polanyitä (1967), jonka mukaan hiljainen tieto on "that which we know but cannot tell" (Eraut 2000).

3 Artikkelin tulokset perustuvat lisensiaatin tutkimukseeni Ikä, osaaminen ja oppiminen. Työntekijöiden käsityksiä osaamisesta ja sen kehittämisestä sekä iän ja ikääntymisen merkityksestä työelämässä. Tutkimus on toteutettu osana Worktow-projektia Jyväskylän yliopiston kasvatustieteen laitoksella. Hanketta on taloudellisesti tukenut myös Suomen Akatemia.

1 Kolmivuotinen tutkimusprojekti (TSER-hanke) käynnistyi marraskuussa 1997 ja siinä tarkasteltiin pk-yritysten yli 45-vuotiaiden työntekijöiden selviämistä muuttuvassa työelämässä, lähtökohtana työssä oppiminen, osaaminen ja koulutus. Tavoitteena oli selvittää mahdollisuuksia paremmin tunnistaa, arvostaa ja hyödyntää ikääntyvien työntekijöiden (kokemusperäistä) osaamista, ikääntyvien työssä oppimista, HRD:n mahdollisuuksia edistää elinikäistä oppimista ja tuottavuutta ja siten ikääntyvien osalta ehkäistä työelämästä syrjäytymistä sekä sitä, millä tavoin iän ja osaamisen suhteen heterogeeninen työvoima voi myötävaikuttaa oppivan organisaation kehittämiseen.

Artikkeli saapui toimitukseen heinäkuussa 2002. Se hyväksyttiin toimituskunnan kokouksessa 3.3.2003. 